\title{
SURVEI PERILAKU MASYARAKAT TERHADAP POPULASI TUNGAU DEBU RUMAH DI SEKITAR RUMAH PENDUDUK KELURAHAN MALALAYANG SATU KECAMATAN MALALAYANG KOTA MANADO
}

\author{
${ }^{1}$ Mikhael Abraham \\ ${ }^{2}$ Victor Pijoh \\ ${ }^{2}$ John Runtuwene
}

\author{
${ }^{1}$ Kandidat Skripsi Fakultas Kedokteran Universitas Sam Ratulangi \\ ${ }^{2}$ Bagian Parasitologi Fakultas Kedokteran Universitas Sam Ratulangi Manado \\ Email:mikhael.abraham@yahoo.co.id
}

\begin{abstract}
Dust contains a variety of air-borne particles that spread in the air. The house dust contains house dust mites which are found most in the furniture of the house. House dust mites can be a serious problem for human health. The temperature and moisture of Manado is suitable for the breeding of house dust mites. This study aimed to determine the behavior of the public towards the house dust mites population around the residential houses in subdistrict Malalayang Satu district Malalayang Manado. This was a descriptive study with using questionnaire. Samples were 100 people obtained by simple random sampling method. This study was conducted in November - December 2012. The results showed that the average level of knowledge of the population was in good category with a score of 4.77 points (maximum 8 points). Respondents' attitude is categorized as good with the average score of 20,01 points (maximum 21 points). Respondent's action is categorized as good with average score of 7.04 points (maximum 10 points). Conclusion: Knowledge, attitude, and action of people in subdistrict Malalayang Satu Malalayang Manado belonged to good category.
\end{abstract}

Keywords: house dust mite, behaviour

\begin{abstract}
Abstrak: Debu merupakan gabungan dari bermacam-macam partikel yang menyebar di udara. Di dalam debu rumah terdapat tungau debu rumah (TDR) yang banyak ditemukan pada perabot-perabot rumah. TDR dapat menjadi masalah serius bagi kesehatan manusia. Suhu dan kelembaban kota Manado cukup ideal bagi perkembangbiakan TDR. Penelitian ini bertujuan untuk mengetahui perilaku masyarakat terhadap populasi TDR di sekitar rumah penduduk kelurahan Malalayang Satu kecamatan Malalayang Manado. Penelitian ini menggunakan metode deskriptif dengan kuesioner. Sampel penelitian berjumlah 100 orang yang diambil berdasarkan simple random sampling. Penelitian dilakukan di kelurahan Malalayang Satu kecamatan Malalayang Manado pada bulan November - Desember 2012. Hasil penelitian memperlihatkan bahwa rata-rata tingkat pengetahuan penduduk masuk dalam kategori baik dengan skor 4,77 poin (maksimal 8 poin). Sikap responden dikategorikan baik dengan skor rata-rata 20,01 poin (maksimal 21 poin). Tindakan responden dikategorikan baik dengan skor rata-rata 7,04 poin (maksimal 10 poin). Simpulan: Pengetahuan, sikap, dan tindakan masyarakat kelurahan Malalayang Satu kecamatan Malalayang kota Manado termasuk kategori baik.
\end{abstract}

Kata kunci: tungau debu rumah, perilaku 
Debu merupakan gabungan dari bermacammacam partikel yang menyebar di udara, termasuk spora jamur, serbuk sari, serat pakaian, dan sebagainya, namun di rumah, selain berasal dari polusi, umumnya debu berasal dari sisa makanan, lapisan kulit luar manusia yang mengelupas, bulu hewan peliharaan seperti anjing atau kucing. ${ }^{1} \mathrm{Di}$ dalam debu rumah terdapat parasit yang biasa dikenal dengan tungau debu rumah (TDR) dan banyak ditemukan pada perabot-perabot rumah. ${ }^{2}$ Tungau adalah hewan berjenis serangga, berkaki delapan, dan ukurannya sebesar debu, kira-kira 0,1$0,3 \mathrm{~mm}$. Jadi hanya bisa kita lihat dengan menggunakan mikroskop. ${ }^{1}$ Tungau debu rumah dapat menjadi masalah yang serius bagi kesehatan manusia. ${ }^{2}$ Alergen TDR merupakan salah satu patogen yang paling penting yang menyebabkan alergi pada asma. $^{3}$ Berbagai studi tentang alergi terhadap TDR di seluruh dunia menunjukkan bahwa TDR selain menyebabkan gejala-gejala asma juga menyebabkan rhinitis, konjungtivitis, dan dermatitis yang sering terjadi saat malam atau pagi hari. ${ }^{4}$

Pada penelitian Sundaru ${ }^{5}$ di Jakarta dari 32,6 gram debu rumah yang berasal dari 20 rumah penderita asma, didapatkan tungau sebanyak 1.480 yang terdiri dari 10 genus. Manan $\mathrm{dkk}^{5}$ melaporkan pada 10 rumah penderita asma, ditemukan 9 genus tungau. Penyakit asma merupakan penyakit lima besar penyebab kematian di dunia. ${ }^{6}$ Ditemukan sebanyak 75-90\% anak-anak yang menderita asma terbukti mempunyai riwayat alergi dalam tubuhnya yang dipicu oleh alergen yang memasuki tubuh seperti tungau yang ada dalam debu rumah, serbuk sari, binatang peliharaan, bahkan dari makanan yang dikonsumsi. ${ }^{7}$

Di Indonesia prevalensi asma sekitar 67\% dan reaksi sensitivitas kulit terhadap TDR cukup tinggi yaitu 58-80\%. ${ }^{5}$ Hasil penelitian International Study on Asthma and Allergies in Childhood menunjukkan bahwa di Indonesia prevalensi penyakit asma meningkat dari 4,2\% pada tahun 1995 menjadi 5,4\% pada tahun 2003.Departemen Kesehatan memperkirakan penyakit asma termasuk 10 besar penyebab kesakitan dan kematian di RS dan diperkirakan 10\% dari 25 juta penduduk Indonesia menderita asma. ${ }^{8}$ Suhu dan kelembaban optimum bagi perkembangan populasi TDR $25-30^{\circ} \mathrm{C}$ dan kelembaban relatif $70-80 \%$ dengan kelembaban kritis 60-65\%. ${ }^{9}$ Suhu udara kota Manado pada siang hari rata-rata $29,40-32,20^{\circ} \mathrm{C}$ dan pada malam hari ratarata $21,60-23,20^{\circ} \mathrm{C}$. Kelembaban udara relatif tinggi dengan rata-rata berkisar antara $75 \%-92 \% .^{10}$ Suhu dan kelembaban kota Manado cukup ideal bagi perkembangbiakan TDR. Berdasarkan uraian di atas maka peneliti akan mengadakan penelitian mengenai survey perilaku masyarakat terhadap populasi TDR di sekitar rumah penduduk kelurahan Malalayang Satu kecamatan Malalayang kota Manado.

\section{METODE PENELITIAN}

Penelitian ini menggunakan metode deskriptif dengan kuesioner. Lokasi penelitian di kelurahan Malalayang Satu kecamatan Malalayang kota Manado. Waktu penelitian dilaksanakan pada November 2012 - Januari 2013.

Populasi penelitian ialah masyarakat di kelurahan Malalayang Satu kecamatan Malalayang kota Manado yang berjumlah 8.697 jiwa. Sampel yang diambil berdasarkan simple random sampling, dan besarnya dihitung dengan menggunakan rumus Snedecor Cochran.

$\mathrm{n}=\frac{4 \mathrm{pq}}{\mathrm{L}^{2}} \quad \mathrm{n}_{1}=\frac{\mathrm{n}}{1+(\mathrm{n} / \mathrm{N})}$

Keterangan : $\mathrm{n}=$ jumlah sampel awal $\mathrm{p}=$ sifat suatu keadaan dalam persen, jika tidak diketahui dianggap 50\%

$\mathrm{q}=100 \%-\mathrm{p}$

$\mathrm{L}=$ derajat ketepatan yang digunakan $(10 \%)$ $\mathrm{N}=$ Jumlah populasi $\mathrm{n}_{1}=$ Jumlah sampel sekarang

Pengumpulan data dalam penelitian ini terdiri dari data tentang identitas responden 
serta variabel penelitian yaitu perilaku masyarakat terhadap peningkatan populasi tungau debu yang terdiri dari tiga bagian yakni pengetahuan, sikap, dan tindakan yang diperoleh melalui wawancara langsung terhadap responden dengan menggunakan kuesioner.

Variabel penelitian dalam segi karakteristik responden yaitu umur, jenis kelamin, pendidikan terakhir dan pekerjaan. Dalam segi perilaku masyarakat yaitu pengetahuan, sikap, dan tindakan. Teknik pengumpulan data dibagi atas data primer dan data sekunder dengan teknik pengolahan data dilakukan dengan menggunakan sistem tabulasi dan dianalisis berdasarkan persentase.

\section{HASIL PENELITIAN DAN BAHASAN}

Berdasarkan karakteristik responden yang dipilih sejumlah 100 orang dimana distribusi umur responden paling banyak antara 26-45 tahun dan paling sedikit adalah responden dengan umur 61 tahun ke atas. Semakin banyak usia seseorang maka semakin bijaksana dan banyak pengalaman/ hal yang telah dijumpai dan dikerjakan untuk memiliki pengetahuan. ${ }^{11}$ Berdasarkan teori tersebut berarti umur responden memengaruhi perilaku responden. Pada kategori pendidikan terakhir responden didapatkan paling banyak setingkat SMA/SMK dan paling sedikit SD. Pekerjaan responden paling banyak adalah tidak bekerja karena banyak dijumpai ibu rumah tangga. Sisanya adalah yang bekerja sebagai PNS dan swasta. Makin tinggi pendidikan, makin mudah seseorang menerima pengetahuan ${ }^{11}$

Berdasarkan penelitian yang dilakukan pada warga kelurahan Malalayang I kecamatan Malalayang didapatkan bahwa rata-rata tingkat pengetahuan mereka masuk dalam kategori baik dengan skor 4,77 poin atau dibulatkan menjadi 5 poin dengan poin maksimal 8 poin. Sikap responden berdasarkan rata-rata penilaian yang diukur dengan skala likert dikategorikan baik dengan rata-rata 20,01 poin yang dibulatkan menjadi 20 poin dengan poin maksimal 21. Tindakan responden yang berdasarkan rata-rata penilaian yang diukur dengan skala Guttman masuk dalam kategori baik dengan rata-rata poin mereka 7,04 poin yang dibulatkan menjadi 7 poin dengan poin maksimal 10 poin.

\section{SIMPULAN}

Dari hasil penelitian dan bahasan disimpulkan bahwa pengetahun, sikap, dan tindakan masyarakat kelurahan Malalayang I kecamatan Malalayang kota Manado terhadap tungau debu rumah tergolong kategori baik.

\section{DAFTAR PUSTAKA}

1. Vitahealth. Asma-Infromasi Lengkap untuk Penderita dan Keluarga. Jakarta: Gramedia Pustaka Utama, 2005; p. 47-8.

2. Faiza A. Hubungan Antara Lama Penggunaan Kasur Kapuk dengan Jumlah Populasi Tungau Debu Rumah di Perumahan PJKA Kelurahan Randusari Semarang. Semarang: Universitas Diponegoro; 2006.

3. Feng $M$, Bing $Y$, Yijun $Z$, Yanagi $U$, Xunjia C.A Study on Indoor Environment Contaminants Related to Dust Mite in Dwellings of Allergic Asthma Patients and of Healthy Subjects. BioScience Trends; 2012, 6(1),7-9.

4. Yudopranoto K. Perbandingan Populasi Tungau Debu Rumah pada Kasur Kapuk dan Non-Kapuk di Perumahan PJKA Kelurahan Randusari Semarang Selatan Jawa Tengah. Semarang: Universitas Diponegoro, 2006.

5. Sungkar S. Aspek Biomedis Tungau Debu Rumah. MKI. 2004;6(54):225-28.

6. Lumbanraja PLH. Distribusi Alergen pada Penderita Rinitis Alergi di Departemen THT-KL FK USU / RSUP H. Adam Malik Medan. Medan: Universitas Sumatera Utara, 2007.

7. Graha C. 100 questions \& Answers: Alergi pada Anak. Jakarta: Elex Media Komputindo, 2010; p. 84.

8. Oemiati R, Sihombing $M$, Qomariah. 
Faktor-Faktor yang Berhubungan dengan Penyakit Asma di Indonesia. Media Litbang Kesehatan. 2010;1(XX):41.

9. Darwanto. Atlas Parasitologi Kedokteran. Jakarta: Gramedia Pustaka Utama, 1994; p.156.

10. Keadaan Iklim. 2012 Januari 28 [cited 2012 Okt 23]. Available from URL http://www.manadokota.go.id/page102-iklim.html.

11. Paramita DP. Hubungan Tingkat Pengetahuan Tentang Dismenorea dengan Perilaku Penanganan Dismenorea pada Siswi SMK YPKK I Sleman Yogyakarta. Surakarta: Universitas Sebelas Maret; 2010. 